\title{
PENGEMBANGAN MEDIA GAME VISUAL NOVEL BERBASIS ETNOMATEMATIKA UNTUK MENINGKATKAN PEMAHAMAN KONSEP PADA MATERI ALJABAR
}

\author{
Sesar Guntur Jabali, Supriyono, Puji Nugraheni \\ Universitas Muhammadiyah Purworejo, Indonesia \\ sesarguntur@gmail.com
}

\begin{abstract}
:
Education was strongly influenced by technological advances, moreover, teachers were required to be creative and innovative. One of them which can be applied for learning media was following existing technological developments. This study aims to produce learning media for ethnomathematics based visual novel games and to determine the validity, practicality and effectiveness to be suitably used by junior high school students. The development model used in this research was the ADDIE (Analysis, Design, Development, Implementation, and Evaluation) development model. This studied was involved 30 students and mathematics teacher at the analysis stage, three experts at the product validation stage and 10 students at the implementation stage. The resulted of the development research were in the form of ethnomathematics-based visual novel game media with a validity score of $86.7 \%$ (very valid criteria), a practicality score of 3.3 (good criteria), a score of $90 \%$ student learning completeness (complete) and a conceptual understanding of $83.7 \%$ (very good criteria). From the resulted of the study it was concluded that the media was suitable to be used and increased students' conceptual understanding because it met the valid, practical and effective criteria.
\end{abstract}

Keywords: conceptual understanding, ethnomatematics, visual novel games

\section{PENDAHULUAN}

Revolusi industri 4.0 merupakan proses dimana kemajuan dan perkembangan dibidang industri dan teknologi mengalami kemajuan yang sangat pesat. Dampak yang sangat terlihat dari perkembangan tersebut salah satunya dibidang pendidikan. Dalam dunia pendidikan, Revolusi industri 4.0 akan memberikan pengaruh yang besar, yakni munculnya beragam sumber belajar dan teknologi yang harus digunakan, khususnya komputer dan handphone. Oleh karena itu, guru dituntut agar bisa berinovasi dalam proses belajar mengajar, agar guru tidak tertinggal pengetahuannya dibandingkan dengan siswanya, khususnya pengetahuan tentang teknologi yang berkembang saat ini. Guru juga dituntut agar menjadi pendidik yang kreatif agar dalam proses belajar mengajar tidak monoton, jika proses pembelajaran ini masih dibiarkan maka akan berakibat siwa menjadi jenuh selama pembelajaran berlangsung. Salah satu solusinya adalah pengunaan media pembelajaran.

Media adalah suatu alat yang berfungsi membantu dalam proses pembelajaran, memperjelas makna, mencapai tujuan pembelajaran. Sama seperti yang dinyatakan oleh Kustandi dalam Abdullah \& Yunianta (2018: 434) media pembelajaran adalah suatu alat yang dapat membantu proses dan memperjelas

Content from this work may be used under the terms of the Creative Commons Attribution- 
makna dalam pembelajaran, sehingga tujuan pembelajaran dapat tercapai. Diperkuat juga berdasarkan pedapat Sutirman (2013: 15) media pembelajaran adalah alat yang dapat untuk menangkap, memproses dan mengkonstruksi informasi visual atau verbal baik berupa grafis, photografis atau elektronis. Dalam hal ini bentuk dari media memiliki banyak jenis. Seels dan Gasgow dalam (Arsyad, 2011) membagi jenis media pembelajaran ke dalam dua kategori luas, yaitu pilihan media tradisional dan pilihan media teknologi mutakhir. Media tradisional adalah media yang menggunakan alat dan bahan tradisional tanpa menggunakan teknologi yang ada, sedangkan media teknologi mutakhir adalah media yang menggunakan teknologi yang ada seperti komputer dan hanphone.

Pembuatan media pembelajaran juga harus mengikuti perkembangan teknologi. Teknologi yang berkembang saat ini adalah micro processor atau dikenal dengan komputer. Salah satu media pembelajaran yang dapat dikembangkan melalui komputer adalah media game. Menurut Fuqoha (2015: 5) Melalui game siswa mendapatkan sesuatu yang menyenangkan, melalui perasaan senang tersebut siswa akan membentuk memori baru. Salah satu jenis game yang ada adalah game visual novel. Game visual novel umumnya dimainkan di komputer, tetapi juga dapat diunduh melalui ponsel berbasis android. Sebagai produk desain komunikasi visual, novel visual mengintegrasikan keterampilan desain grafis melalui pilihan gaya visual, desain karakter visual, dan desain naratif visual melalui konstruksi cerita komunikatif interaktif. Dalam hal ini, elemen-elemen visual desain saling terkait, seperti garis, bentuk, bidang, warna, tekstur, ruang, dan gerak, untuk menghasilkan keindahan dan daya tarik dalam visualisasinya. Kesatuan elemen harus tetap mempertimbangkan elemen harmoni, keseimbangan, dan fokus visual yang akan menjadi titik vokal. Pratama, dkk. (2018 : 327) menyatakan bahwa game visual novel memiliki kelebihan membangun presepsi visual untuk pengguna, karena ketika bermain game tersebut memvisualisasikan imajinasi dengan merasakan melalui penglihatan. Sehingga game visual novel ini dapat digunakan untuk mencapai tujuan mata pelajaran matematika.

Kemampuan pemahaman konsep merupakan salah satu tujuan pembelajaran matematika. Sebagaimana dinyatakan dalam (Depdiknas, 2006) salah satu tujuan mata pelajaran matematika untuk semua jenjang pendidikan dasar dan menengah adalah agar siswa mampumemahami konsep matematika,menjelaskan keterkaitan antarkonsep, dan mengaplikasikan konsep atau algoritma secara luwes, akurat, efisien, dan tepat dalam pemecahan masalah. Kilpatrick dalam Pratiwi, dkk. (2019: 179) menyatakan bahwa pemahaman konsep merupakan dasar dalam mengkonstruksi pengetahuan matematika sebab pemahaman konsep adalah kemampuan dalam memahami ide-ide matematika secara menyeluruh dan fungsional. Dengan pemahaman konsep tinggi siswa dapat lebih mengetahui tentang ide-ide matematika yang masihtersembunyi.untuk mencapai tujuan pendidikan yaitu semua siswa memiliki kemampuan pemahaman konsep yang baik perlu adanya inovasi pembelajaran, salah satunya mengaitkan pendidikan dengan budaya sekitar. Sehingga selain mempelajari matematika siswa juga lebih mengenal budaya disekitarnya atau disebut juga etnomatematika.

D'Ambrosio (2001: 67) menyatakan bahwa Etnomatematika memiliki tujuan yaitu mempelajari bagaimana siswa untuk memahami, mengartikulasikan, mengolah, dan akhirnya menggunakan ide-ide matematika, konsep, dan praktek-

Alifmatika: Jurnal Pendidikan dan Pembelajaran Matematika, Desember 2020, Vol. 2, No. 2 


\section{Sesar Guntur Jabali, Supriyono, \& Puji Nugraheni}

praktek tersebut dan diharapkan akan dapat memecahkan masalah yang berkaitan dengan aktivitas sehari-hari mereka. Sedangkan menurut Brandt \& Chernoff dalam Hasanah, dkk. (2019: 185) etnomathematics adalah matematika berbasis budaya, kemudian diintegrasikan ke dalam kelas matematika. Sehingga dapat diartikan bahwa etnomatematika adalah matematika yang menggunakan ide-ide, konsep-konsep dan praktek-praktek dalam budaya masyarakat, selanjutnya diintregasikan dalam kelas. Pada zaman berkemajuan, sebagian besar siswa rentan melupakan budaya yang ada di negara Indonesia. Siswa cenderung lebih senang belajar melalui media-media elektronik seperti internet dan gadget yang sebagian besar mengakses budaya asing. Menurut hasil survei (TheAsianparent Indonesia, 2014) didapatkan bahwa anak-anak dan remaja dalam penggunaan gadget dan internet, $72 \%$ mengakses video dan game. Untuk menghadapi permasalahan di atas perlu diciptakan media pembelajaran. Salah satunya yaitu game visual novel yang mengandung unsur-unsur budaya agar menanamkan unsur kebudayan di dalam pelajaran maupun pada kehidupan siswa. Hal tersebut berdasarkan (Rosa, dkk., 2016) menyatakan bahwa melalui etnomatematika siswa dapat terbantu dalam mengetahui lebih banyak tentang ralitas, budaya, masyarakat dan diri mereka sendiri

Pada mata pelajaran matematika SMP kelas VII semester ganjil (As'ari, Tohir, Valentino, Imron, \& Taufiq, 2016), materi tentang aljabar merupakan salah satu yang dianggap sulit oleh sebagian siswa. Berdasarkan hasil observasi pada saat melaksanakan les dan melaksanakan kegiatan magang selama dua bulan. Siswa merasa kesulitan saat membedakan variabel, konstanta dan suku dikarenakan tidak memahami definisi dan konsep pada materi aljabar. Hal tersebut juga diperkuat oleh hasil penelitian dari Suciyani \& Jannah (2014: 138) kesulitankesulitan siswa pada materi aljabar meliputi kesulitan untuk mengingat dan memahamai definisi koefisien, variabel, konstanta serta kesulitan dalam membedakan suku sejenis dan tidak sejenis dalam bentuk aljabar. Diharapkan media pembelajaran game visual novel ini dapat membantu pendidik dalam memberikan materi aljabardan dapat memberikan pendidikan budaya untuk siswa.

Media game visual novel berbasis etnomatematika dibuat dengan menggunakan aplikasi tyranobuilder yang memiiki fitur lengkap tetapi mudah digunakan oleh pemula. Media juga dilengkapi dengan panduan sehingga siswa dapat dengan mudah menggunakannya dalam proses belajar mengajar sebagai media perantara untuk menjelaskan materi. Materi yang digunakan yaitu operasi aljabar sub bab bentuk aljabar, pengurangan dan penjumlahan aljabar. Materi dikaitkan dengan kehidupan sehari-hari berupa wayang pada bagian perngenalan variabel yaitu dengan menggnakan permisalan. Konsep penjelasan materi metode deduktif yaitu dengan penjelasan tentang hal-hal yang dikaitkan dengan kehidupan sehari-hari selanjutnya dibawa ke bentuk kalimat matematika sehingga menstimulus pemahaman konsep.

Penelitian yang telah dilakukan oleh (Abdullah \& Yunianta, 2018), (Amirulloh dkk., 2019), (Rahmawati \& Leksono, 2020) dan (Rofiqoh dkk., 2020) mengembangkan game matematika. Akan tetapi yang membedakan dengan penelitian ini adalah penggunaan jenis game, materi dan basis budaya. Media yang dikembangkan dalam penelitian ini memiliki ciri khas dan menonjolkan unsur

Alifmatika: Jurnal Pendidikan dan Pembelajaran Matematika, Desember 2020, Vol. 2, No. 2 
budaya dalam alur cerita. Alur cerita dalam media game visual novel yaitu karakter menjelaskan tentang materi dan melakukan tanya jawab interaktif dengan penguna.Karakter yang digunakan dalam game visual novel yaitu wayang punakawan dengan tujuan mengenalkan budaya daerah kepada siswa. Punakawan dalam pewayangan adalah pembimbing dari pandhawa pada cerita wayang mahabarata, sehingga penggunaan sebagai pembimbing dan pengajar dalam media merupakan hal tepat. Punakawan juga merupakan karakter yang memiliki ciri khas sendiri dan sifat-sifat yang dapat diteladani. Diharapkan siswa selain mengenal budaya juga dapat menteladani sifat-sifat punakawan.

\section{METODE PENELITIAN}

Jenis penelitian yang dilakukan adalah penelitian pengembangan (Reserch and Development) dengan model ADDIE. Menurut Kurt, Sehart dalam Mulyatiningsih (2011: 199) model ADDIE terdiri dari 5 tahappengemabangan antara lain Analisys atau analisis, Design atau perencanaan, Development atau pengembangan, Implementation atau penerapan, dan Evaluation atau evaluasi. Desain penelitian pada penelitian ini dapat digambarkan melalui bagan dibawah ini.

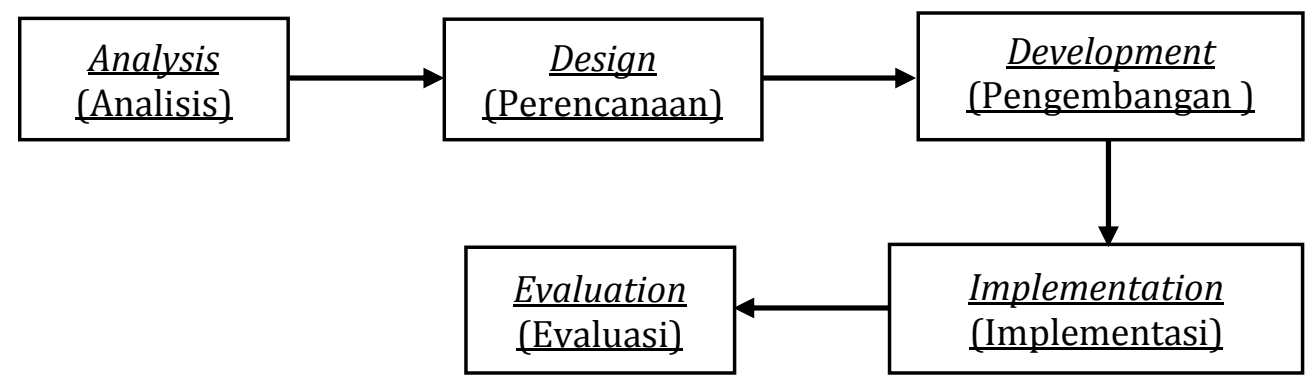

Gambar 1.Bagan Prosedur Pengembangan Dengan Model Addie

1. Tahap Analysis (Analisis)

Pada tahap analisis ini bertujuan untuk menganalisis kebutuhan pembelajaran matematika di jenjang Sekolah Menengah Pertama (SMP). Pada analisis kebutuhan ini peneliti melakukan observasi dan wawancara. Hasil dari analisis yang telah dilakukan akan dijadikan sebagai acuan bahwa peneliti akan menyusun dan mengembangkan media pembelajaran media Game Visual Novel matematika berbasis etnomatematika. Subjek pada tahap ini yaitu guru dan 30 siswa kelas VII MTs Al-Iman Bulus Kabupaten Purworejo.

2. Tahap Design (Perancangan)

Tahap ini bertujuan untuk meniapkan rancangan awal media atau produk. Tahap ini terdiri dari tiga langkah, yaitu:

a. Desain teori

Desain teori disesuaikan dengan dengan media yang akan dikembangkan.

b. Pemilihan Media

Pemilihan media disesuaikan dengan tujuan untuk menyampaikan materi pelajaran. Dalam pembelajaran matematika tentang penerapan operasi 


aljabar, dengan penggunaan media game visual novelberbasis
etnomatematika.
c. Rancangan Awal (Desain Awal)
Rancangan awal yaitu rencana awal produk yang akan dikembangkan
3. Tahap Development (Pengembangan)
Pada tahap ini dibagi menjadi dua yaitu pembuatan produk awal dan validasi
ahli. Validasi ahli dengan tujuan untuk memperbaiki produk awal yang telah
dibuat. Validasi dilakukan oleh tiga dosen ahli, yaitu dosen ahli media, dosen ahli
materi dan dosen ahli budaya. Validasi dilakukan dengan cara pemberian angket
(lembar validasi), kemudian peneliti merevisi game visual novel berbasis
etnomatematika sesuai dengan komentar, saran dan penilaian yang diberikan oleh
validator, sehingga menghasilkan desain perbaikan (desain awal yang sudah
diperbaiki).

4. Tahap Implementation (Implementasi)

Pada tahap ini media yang telah dikembangkan diimplementasikan pada situasi yang nyata di kelas, yaitu dengan uji coba produk. Uji coba produk melibatkan subjek sebanyak 10 siswa. Tahap pada uji coba produk dilakukan dengan memberikan pembelajaran menggunakan media. Setelah pembelajaran diberikan angket tentang respon siswa terhadap pengembangan game visual novel berbasis etnomatematika untuk mengukur kepraktisan media yang dikembangkan. 5. TahapEvaluation (Evaluasi)

Tahap evaluasi bertujuan untuk mengetahui keefektifan dari media yang dikembangkan. Tahap evaluasi ini dilakukan dengan menganalisis hasil tes pemahaman konsep.

Subjek penelitian berjumlah 10 siswa di MTs Al-Iman Bulus Kabupaten Purworejo. Penelitian ini dilaksanakan pada semester ganjil tahun pelajaran 2020/2021 selama 2 bulan yaitu pada bulan juli dan Agustus. Teknik pengumpulan data menggunakan Observasi, wawancara kepada guru dan siswa untuk analisis kebutuhan dan analisis materi, validasi kepada ahli media, ahli materi dan ahli budaya menggunakan lembar validasi, memberikan angket respon kepada siswa untuk mengetahui tingkat keprakraktisan media serta tes pemahaman konsep siswa untuk mengetahui ketuntasan belajar dan tingkat pemahaman konsep siswa. Instrumen yang digunakan yaitu berupa pedoman wawancara terhadap guru dan siswa, lembar validasi ahli materi, ahli media, ahli budaya, angket respon untuk siswa dan soal tes pemahaman konsep.

Analisis kelayakan dilihat dari kevalidan, kepraktisan dan kepraktisan. Kevalidan diperoleh dari angket validasi dosen ahli media, dosen ahli materi dan dosen ahli budaya.Analisis data penilaian ahli media, materi dan budaya dianalisis menggunakan skala likert. Menurut Indarti dalam Wardani (2019: 2484) persentase skor validasi diperoleh dengan menggunakan rumus sebagai berikut:

$$
P(\%)=\frac{\text { Jumlah skor hasil pengumpulan data }}{\text { skor maksimal }} \times 100 \%
$$

Selanjutnya skor yang diperoleh dalam penelitian ini digolongkan dalam kriteria dengan menggunakan skala sebagai berikut.

Alifmatika: Jurnal Pendidikan dan Pembelajaran Matematika, Desember 2020, Vol. 2, No. 2 
Tabel 1. Kriteria Kevalidan

\begin{tabular}{cc}
\hline Kriteria & Persentase \\
\hline Tidak Valid & $0 \%-20 \%$ \\
Kurang Valid & $21 \%-40 \%$ \\
Cukup Valid & $41 \%-60 \%$ \\
Valid & $61 \%-80 \%$ \\
Sangat Valid & $81 \%-100 \%$ \\
\hline
\end{tabular}

Sugiyono dalam Wardani, A, (2019: 2484)

Dalam penelitian ini, suatu produk dikatakan praktis jika dapat diterapkan di lapangan. Berdasarkan Khabibah dalam Wicaksono DKK (2014: 539), kegiatan analisis kepraktisan produk dapat dilakukan sebagai berikut.

a. Menentukan rata-rata dari semua responden untuk tiap kriteria

$A_{i}=\frac{\sum_{=1}^{n} K_{i j}}{n}$

Keterangan:

$A_{i}$ : skor rata-rata aspek ke- $i$

$K_{i j}$ : rata-rata untuk aspek ke- $i$ dan kriteria ke- $j$

$n$ : banyaknya kriteria dalam aspek ke- $i$

b. Menentukan Nilai Kepraktisan

$K M=\frac{\sum_{j=1}^{m} A_{i}}{m}$

Keterangan:

$K M$ : nilai akhir kepraktisan

$A_{i}$ : skor rata-rata aspek ke- $i$

c. Mencocokan rata-rata total dengan kriteria kepraktisan. Berikut kriteria kepraktisan menurut Khabibah dalam Wicaksono DKK (2014: 539)

Tabel 2. Kriteria Kepraktisan

\begin{tabular}{cc}
\hline $\begin{array}{c}\text { Interval Rata-Rata } \\
\text { Skor }\end{array}$ & Tingkat Kepraktisan \\
\hline $4 \leq K M<5$ & Sangat Baik \\
$3 \leq K M<4$ & Baik \\
$2 \leq K M<3$ & Kurang Baik \\
$1 \leq K M<2$ & Tidak Baik \\
\hline
\end{tabular}

Analisis data keefektikan menurut Khabibah dalam Nurtasari, H. R. \& Manoy, (2016: 169) Media pembelajaran dikatakan efektif, jika skor tes hasil belajar siswa setelah mendapatkan pembelajaran dengan media pembelajaran adalah tuntas yang dimana pada penelitian ini tolak ukurnya adalah KKM mata pelajaran

Alifmatika: Jurnal Pendidikan dan Pembelajaran Matematika, Desember 2020, Vol. 2, No. 2 


\section{Sesar Guntur Jabali, Supriyono, \& Puji Nugraheni}

matematika.Media pembelajaran dapat dikatakan efektif jika $\geq 75 \%$ dari seluruh subyek uji coba memenuhi ketuntasan belajar.

Dengan demikian, untuk mengetahui kemampuan siswa dalam memahami konsep diperlukan indikator Menurut Sari dalam Sari (2017: 44) indikator pemahaman konsep yaitu:

Siswa dapat:

a. Menyatakan ulang sebuah konsep,

b. Mengklasifikasikan objek-objek menurut sifat-sifat tertentu (sesuai dengan konsepnya),

c. Memberikan contoh dan non contoh dari konsep,

d. Menyajikan konsep dalam berbagai bentuk representasi matematis,

e. syarat perlu atau syarat cukup suatu konsep,

f. Menggunakan, memanfaatkan dan memilih prosedur atau operasi tertentu, dan Mengaplikasikan konsep atau algoritma pemecahan masalah

\section{HASIL DAN PEMBAHASAN}

Berdasarkan prosedur penelitian yang telah dikemukakan yakni dengan menggunakan model ADDIE pada pengembangan game visual novel berbasis etnomatematika terdiri dari 5 tahapan, meliputi: analysis, design, development, implementation, dan evaluation. Tahapan-tahapan tersebut secara rinci akan dijelaskan sebagai berikut.

\section{Tahap Analisis (Analysis)}

Pada tahap ini, dilakukan analisis kebutuhan dan analisis materi.

a. Analisis kebutuhan

Analisis kebutuhan dilakukan dengan cara melakukan wawancara terhadap guru dan siswa. Hasil wawancara menunjukan masih kurangnya media pembelajaran yang digunakan di sekolah dan kesulitan siswa dalam memahami konsep materi khususnya aljabar. sehingga perlu adanya media pembelajaran untuk mempermudah siswa dalam memahami materi.

b. Analisis materi

Hasil wawancara kepada guru menyatakan bahwa materi operasi aljabar merupakan salah satu materi yang dianggap sulit oleh siswa.Karena siswa masih kesulitan dalam membayangkan model abstrak dari konsep aljabar dan merupakan tugas dari pengajar untuk membawa model abstrak matematika menuju ke model semi realistik atau ke model realistik.

\section{Tahap Perencanaan (Design)}

Tahap ini terdiri dari 2 tahap yaitu desain teori dan desain produk.Pada desain teori dijelaskan wayang adalah bagian dari etnomatematika, sedangkanetnomatematika adalah bagian dari pembelajaran ralistik yang diharapkan dapat meningkatkan pemahaman konsep serta perancangan soal evaluasi berdasarkan indikator pemahaman konsep. Sedangkan desain produk meliputi pemilihan media, penyusunan scene dan pembuatan desain karakter.

Alifmatika: Jurnal Pendidikan dan Pembelajaran Matematika, Desember 2020, Vol. 2, No. 2 


\section{Tahap Pengembangan (Development)}

Pada tahap ini dilakukan proses pembuatan produk awal dan valdasi media yang dilakukan oleh dosen ahli media, materi dan budaya terhadap desain awal. Berikut hasil produk awal:
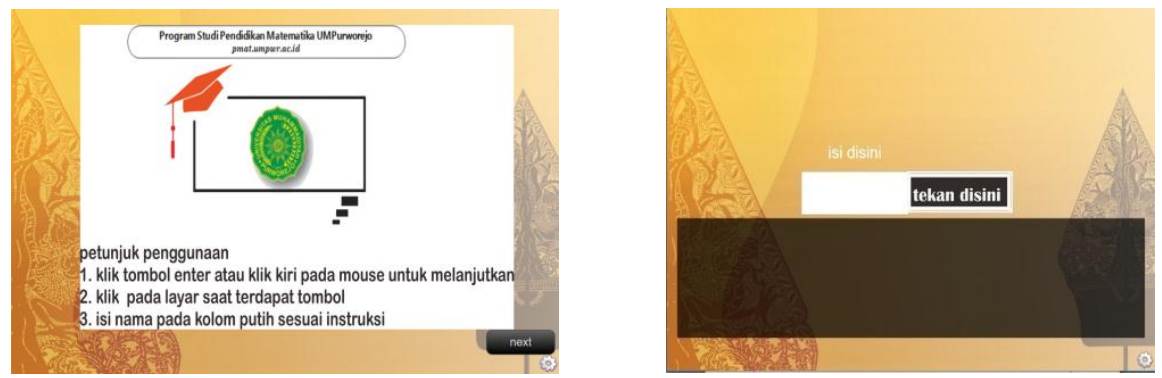

Gambar 2. Petunjuk penggunaan
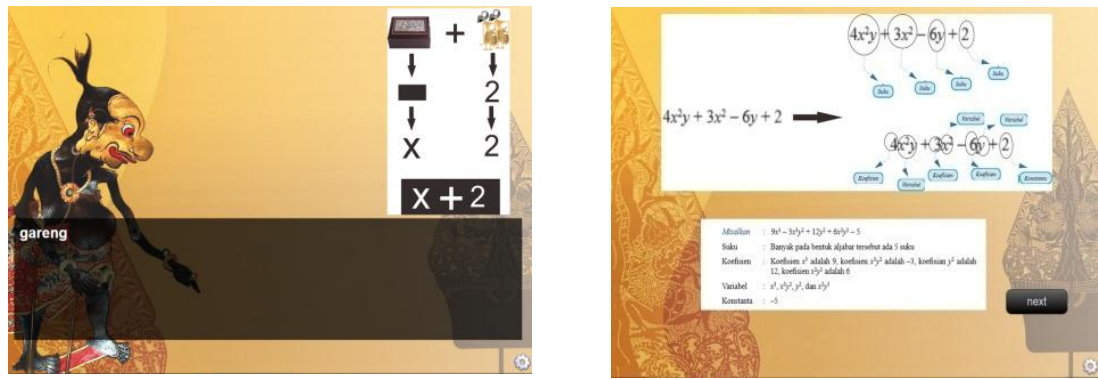

Gambar 3. Aktivitas pengenalan bentuk aljabar
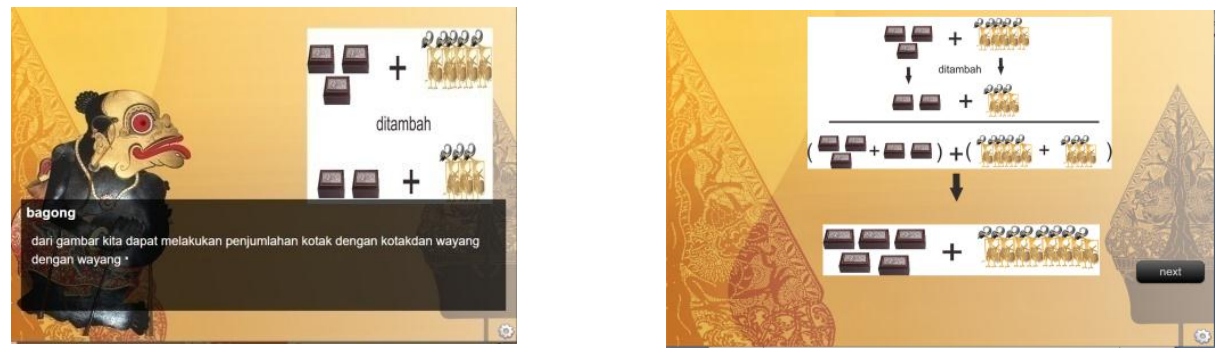

Gambar 4. Aktivitas pengenalan konsep penjumlahan bentuk aljabar
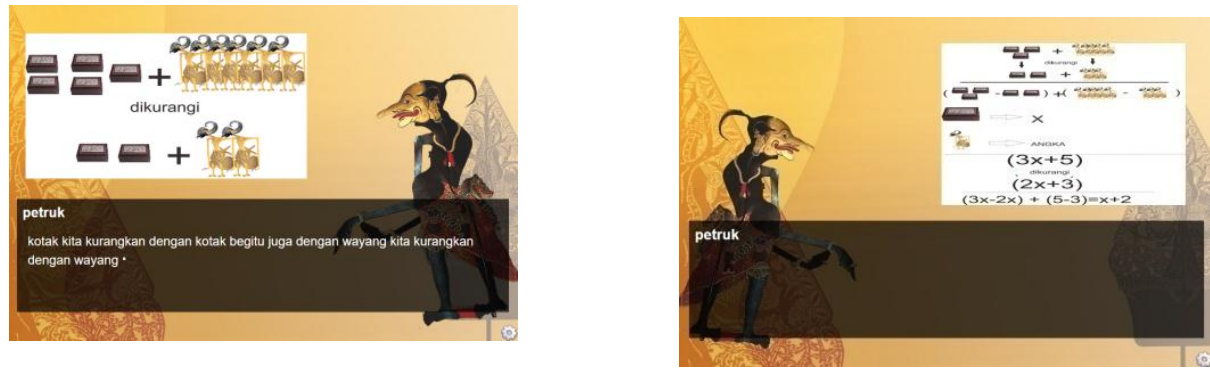

Gambar 5. Aktivitas pengenalan konsep pengurangan bentuk aljabar

Alifmatika: Jurnal Pendidikan dan Pembelajaran Matematika, Desember 2020, Vol. 2, No. 2 


\section{Sesar Guntur Jabali, Supriyono, \& Puji Nugraheni}
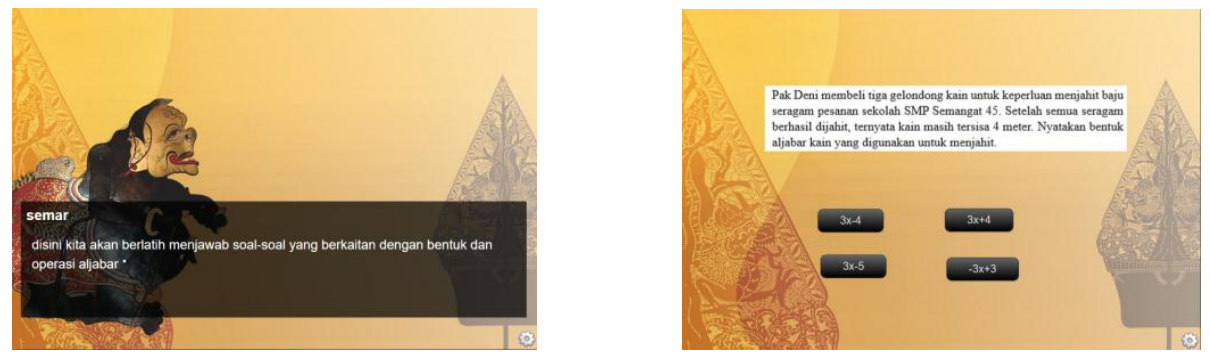

Gambar 6. Aktivitas latihan soal

Penilaian terhadap media yang dilakukan oleh ahli media terdiri dari tiga aspek, yaitu bahasa, grafika dan penyajian.penilaian yang dilakukan oleh ahli materi terdiri dari aspek isi atau materi dan penilaian oleh ahli budaya yaitu aspek budaya. Berikut tabel hasil validasi game visual novel berbasis etnomatematika oleh tiga dosen ahli.

Tabel 3. Hasil Rata-Rata Validasi Dosen Ahli

\begin{tabular}{clcc}
\hline No. & Aspek & $\begin{array}{c}\text { Nilai } \\
\text { Persentase } \\
\text { Rata-Rata }\end{array}$ & Kriteria \\
\hline 1. & Ahli media & $93,3 \%$ & Valid \\
2. Ahli materi & $80 \%$ & Valid \\
3. Ahli budaya & $90 \%$ & Valid \\
Rata-rata & $\mathbf{8 6 , 7 \%}$ & Valid \\
\hline
\end{tabular}

1) Hasil validasi media pembelajaran game visual novel berbasis etnomatematika oleh ahli media.

Penilaian yang dilakukan pada ahli media meliputi tiga aspek meliputi aspek bahasa, grafika dan penyajian.berikut penjelasan ketiga aspek tersebut:

a) Aspek bahasa

Bahasa pada media game visual novel sesuai dengan PUEBI, jelas dan mudah dipahami.

b) Aspek Grafika warna, gambar, background, karakter dan video serasi, penggunaan dan tata letak tombol dan gambar pada media sesuai.

c) Aspek Penyajian

Sampul awal pada media game visual novel menarik, instruksi penggunaan game visual novel mudah dipahami, karakter pada game visual novel menarik, dialog karakter memiliki bahasa yang mudah dipahami dan latihan soal pada media game visual novel mudah digunakan dan dipahami.

Hal tersebut dilihat dari hasil penilaian ahli media mendapatkan persentase 92\% (kategori sangat valid).

Masukan dan saran dari ahli media yaitu agar game yang dikembangkan dapat digunakan pada handphoneakan tetapi media hanya bisa digunakan pada komputer.

Alifmatika: Jurnal Pendidikan dan Pembelajaran Matematika, Desember 2020, Vol. 2, No. 2 
2) Hasil validasi media pembelajaran game visual novel berbasis etnomatematika oleh ahli materi

Penilaian yang dilakukan pada ahli materi meliputi aspek isi/materi. Dari penilaian ahli materi diperoleh bahwa media game visual novel berbasis etnomatematika sesuai dengan kompetensi dasar (KD) dan indikator serta contoh, petunjuk dan soal jelas dan mudah dipahami. Hal tersebut dilihat dari hasil penilaian ahli media mendapatkan persentase $80 \%$ (kategori sangat valid).Masukan dan saran dari ahli materi yaitu materi harus lebis spesifik dan tetap menggunakan alur permisalan yang sesuai.

3) Hasil validasi media pembelajaran game visual novel berbasis etnomatematika oleh ahli budaya

Penilaian yang dilakukan pada ahli budaya meliputi aspek budaya. Dari penilaian ahli budaya diperoleh bahwa media game visual novel berbasis etnomatematika memiliki karakter yang meencerminkan budaya jawa tengah serta dinyatakan berbasis budaya. Hal tersebut dilihat dari hasil penilaian ahli budaya mendapatkan persentase $80 \%$ (kategori sangat valid).

Revisi dan saran dari ahli budaya adalah mengganti kata "PUNOKAWAN" menjadi "PUNAKAWAN" pada halaman depan dari game visual novel dan mengganti musil latar belakang (backsound) menjadi lebih menunjukan adat jawa seperti music gamelan.

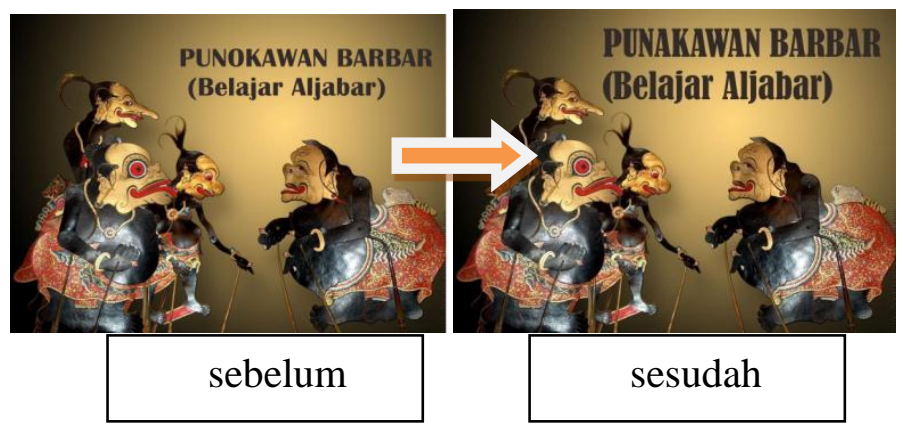

Gambar 7. Revisi oleh ahli budaya

Berdasarkan pada validasi yang dilakukan oleh ahli media, ahli materi dan ahli budaya disimpulkan media game visual novel berbasis etnomatematika dikatakan valid dan dapat digunakan dengan skor rata-rata persentasi yang diperoleh sebesar 86,7\% (kategori sangat valid).

\section{Tahap Implementasi (Implementation)}

Tahap ini dilakukan uji coba terhadap produk yang dikembangkan, yaitu media game visual novel berbasis etnomatematika. Pada uji coba produk dilakasanakan pengujian media dengan pembelajaran berdasarkan rancangan pelaksanaan pembelajaran yang telah dibuat terhadap 10 siswa kelas VII MTs AlIman Bulus Purworejo. Data hasil respon siswa terhadap media game visual novel berbasis etnomatematika berdasarkan angket yang diisi sesuai keyakinan siswa. 
Tabel 4. Hasil Respon Siswa

\begin{tabular}{ccc}
\hline No & Aspek & Rata-rata Aspek \\
& & \\
\hline 1. & Penyajian & 3,3 \\
2. & Isi/Materi & 2,9 \\
3. & Bahasa & 3,7 \\
4. & Grafika & 3,3 \\
5. & Pembelajaran & 3,2 \\
6. & Etnomatematika & 3,7 \\
& Jumlah & 20,1 \\
\hline
\end{tabular}

Berdasarkan Tabel 4 menunjukkan bahwa perhitungan diperoleh nilai akhir kepraktisan sebesar 3,3. Berdasarkan kriteria kepraktisan menurut Khabibah dalam Wicaksono (2014: 539) media game visual novel berbasis etnomatematika memiliki nilai kepraktisan berkategori baik karena memiliki nilai akhir kepraktisan $3 \leq \mathrm{KM}<4$ yaitu 3,3. Media game visual novel berbasis etnomatematika mudah digunakan, memiliki bahasa, ilustrasi dan materi yang jelas serta mudah dipahami dan menambah pengetahuan siswa tentang budaya wayang khususnya punakawan. Hal tersebut dilihat dari rata-rata yang diperoleh yaitu 3,35 dengan kategori kepraktisan baik. Media yang memiliki kategori kepraktisan baik berarti media tersebut mudah digunakan dan membantu siswa dalam proses pembelajaran materi.

\section{Tahap evaluasi (evaluation)}

Evaluasi atau evaluation bertujuan untuk mengetahui keefektifan media game visual novel berbasis etnomatematika. Tahap ini dilakukan setelah pembelajaran pada implementasi dengan pemberian soal tes pemahaman konsep kepada siswa. Pada Tabel 5 berikut merupakan hasil tes pemahaman konsep siswa.

Tabel 5. Hasil Tes Pemahaman Konsep

\begin{tabular}{lcl}
\hline \multicolumn{1}{c}{ Indikator } & $\begin{array}{c}\text { Rata-rata } \\
\text { Persentasi (\%) }\end{array}$ & Kategori \\
\hline $\begin{array}{l}\text { Menyatakan ulang sebuah konsep, } \\
\begin{array}{l}\text { Mengklasifikasikan objek-objek menurut sifat- } \\
\text { sifat tertentu (sesuai dengan konsepnya), }\end{array}\end{array}$ & $100 \%$ & Sangat baik \\
$\begin{array}{l}\text { Memberikan contoh dan non contoh dari } \\
\text { konsep }\end{array}$ & $80 \%$ & Baik \\
$\begin{array}{l}\text { Menyajikan konsep dalam berbagai bentuk } \\
\text { representasi matematis }\end{array}$ & $90 \%$ & Sangat baik \\
Menyajikan konsep dalam berbagai bentuk & $70 \%$ & Baik
\end{tabular}




\begin{tabular}{lcl}
\hline \multicolumn{1}{c}{ Indikator } & $\begin{array}{c}\text { Rata-rata } \\
\text { Persentasi (\%) }\end{array}$ & Kategori \\
\hline $\begin{array}{l}\text { representasi matematis } \\
\text { syarat perlu atau syarat cukup suatu konsep }\end{array}$ & $80 \%$ & Baik \\
$\begin{array}{l}\text { Menggunakan, memanfaatkan dan memilih } \\
\text { prosedur atau operasi tertentu, }\end{array}$ & $80 \%$ & Baik \\
$\begin{array}{l}\text { Mengaplikasikan konsep atau algoritma } \\
\text { pemecahan masalah }\end{array}$ & $90 \%$ & Sangat baik \\
Rata-rata keseluruhan indikator & $83,7 \%$ & Sangat baik \\
\hline
\end{tabular}

Dari data yang diperoleh menunjukkan bahwa hasil tes pemahaman konsep siswa setelah dilakukan pembelajaran menggunakan media game visual novel berbasis etnomatematika dikatakan tuntas dan meningkatkan pemahaman konsep karena keseluruhan siswa mendapatkan nilai lebih dari KKM yang sudah ditentukan yaitu 71 dengan presentasi ketuntasan belajar adalah $90 \%$ dan memiliki persentasi pemahaman konsep sebesar 83,7\%.

Setelah mendapatkan data kemudian dianalisis sehingga diperoleh hasil akhir. Penilaian kelayakan media game visual novel berbasis etnomatematika diukur melalui kevalidan, kepraktisan, dan keefektifan. Berdasarkan analisis uji kevalidan oleh (ahli media, ahli materi dan ahli budaya), uji kepraktisan melalui respon siswa dan uji kefektifan dapat disimpulkan bahwa media game visual novel berbasis etnomatematika dinyatakan layak (valid, praktis dan efektif).

Kemampuan Pemahaman Konsep Siswa yang telah diukur melalui tes pemahaman konsepdiperoleh databahwa siswa secarakeseluruhan mampu memenuhi kriteria yang ada. Kriteria berupa indikator-indikator pemahaman konsep. Rata-rata dari nilai persentase yang diperoleh adalah 83,7\% dengan kategori sangat baik. Oleh karena itu dapat dartikan bahwa siswa telah memiliki pemahaman konsep tentang materi aljabar dengan sangat baik.

\section{KESIMPULAN DAN SARAN}

Berdasarkan hasil penelitian dan pembahasan diperoleh simpulan pada penelitian yaitu media game visual novel berbasis etnomatematika untuk meningkatkan pemahaman konsep siswa SMP pada materi operasi aljabar yang telah dikembangkan layak digunakan juga meningkatkan pemahaman konsep siswa karena memenuhi kriteria valid, praktis dan efektif. Berdasarkan analisis uji kevalidan oleh (ahli media, ahli materi dan ahli budaya) mendapat skor persentasi rata-rata $86,7 \%$ dengan kategori sangat valid, uji kepraktisan melalui respon siswa mendapat skor rata-rata 3,3 dengan kategori kepraktisan baik, uji kefektifan dan analisis kemampuan pemahaman konsep siswa melalui tes pemahaman konsep mendapat ketuntasan belajar sebesar $90 \%$ dan kemampuan pemahaman konsep sebesar $83,7 \%$.

Berdasarkan hasil penelitian, saran yang diberikan oleh peneliti yaitu Pengembangan media perlu dilakukan untuk materi matematika yang lain, agar lebih mempermudah siswa dan guru dalam proses pembelajaran.Media game

Alifmatika: Jurnal Pendidikan dan Pembelajaran Matematika, Desember 2020, Vol. 2, No. 2 
visual novel berbasis etnomatematika perlu diuji cobakan dengan mengimplementasikan langusng kepada siswa pada ranah yang lebih luas.

\section{DAFTAR PUSTAKA}

Abdullah \& Yunianta. (2018). Pengembangan Media Pembelajaran Matematika Trigo Fun Berbasis Game Edukasi Menggunakan Adobe Animate Pada Materi Trigonometri. AKSIOMA: Jurnal Program Studi Pendidikan Matematika, 7(3), 434-443.

Amirulloh, T. R. A., Risnasari, M., \& Ningsih, P. R. (2019). Pengembangan Game Edukasi Matematika (Operasi Bilangan Pecahan) Berbasis Android Untuk Sekolah Dasar. Jurnal Ilmiah Edutic, 5(2), 115-123.

Arsyad, A. (2011). Media Pembelajaran. Jakarta: Raja grafindo Persada.

As'ari, A. R., Tohir, M., Valentino, E., Imron, Z., \& Taufiq, I. (2016). Matematika untuk SMP/MTs kelas VII Semester 1. Jakarta: Pusat Kurikulum dan Perbukuan, Balitbang, Kemdikbud.

D'Ambrosio, U. (2001). General remarks on ethnomathematics. ZDM, 33(3), 67-69.

Departemen Pendidikan Nasional. (2006). Peraturan Menteri Pendidikan Nasional No. 22,23, 24. Jakarta: Depdiknas.

Fuqoha, A. A. N. (2015). Pengembangan game RPG (Role Play Game) sebagai media pembelajaran berbasis guided inquiry pada materi segiempat dan segitiga untuk siswa SMP kelas VII. Skripsi, Yogyakarta: Universitas Negeri Yogyakarta.

Hasanah, S. I., Hafsi, A. R., \& Zayyadi, M. (2019). Pengembangan Lembar Kerja Siswa Berbasis Etnomatematika Dalam Membangun Pemahaman Konsep Siswa. Jurnal Pendidikan Matematika dan IPA, 10(2), 183-191. https://doi.org/10.26418/jpmipa.v10i2.29609

Mulyatiningsih, E. (2014). Metode Penelitian Terapan Bidang pendidikan. Bandung: AlfaBeta.

Nurtasari, H. R. \& Manoy, J. T. (2016). Pengembangan Lembar Kegiatan Siswa (LKS) dengan Media Tangram pada Pembelajaran Matematika Materi Jajargenjang dan Belahketupat. Jurnal Ilmiah Pendidikan Matematika, 3(5), 111.

Pratama, D., Wardani, W. G. W., \& Akbar, T. (2018). The visual elements strength in visual novel game development as the main appeal. Mudra Jurnal Seni Budaya, 33(3), 326-333. https://doi.org/10.31091/mudra.v33i3.455

Pratiwi, N. P. K. A., Astawa, I. W. P., \& Mahayukti, G. A. (2019). Missouri Mathematics Project (MMP), Pemahaman Konsep Matematika, dan Kepercayaan Diri Siswa. Jurnal Elemen, 5(2), 178-189. https://doi.org/10.29408/jel.v5i2.1317

Rahmawati, I., \& Leksono, I. P. (2020). Pengembangan Game Petualang untuk Pembelajaran Berhitung. Edcomtech Jurnal Kajian Teknologi Pendidikan, 5(1), 11-23. 
Rofiqoh, I., Puspitasari, D., \& Nursaidah, Z. (2020). Pengembangan Game Math Space Adventure Sebagai Media Pembelajaran Pada Materi Pecahan Di Sekolah. Lentera Sriwijaya: Jurnal Ilmiah Pendidikan Matematika, 2(1), 41-54.

Rosa, M., D’Ambrósio, U., Orey, D. C., Shirley, L., Alangui, W. V., Palhares, P., \& Gavarrete, M. E. (2016). Current and future perspectives of ethnomathematics as a program. Springer Nature.

Sari, P. (2017). Pemahaman Konsep Matematika Siswa pada Materi Besar Sudut Melalui Pendekatan PMRI. Jurnal Gantang, 2(1), 41-50. https://doi.org/10.31629/jg.v2i1.60

Suciyani, E., \& Jannah, M. H. (2014). Identifikasi kesulitan siswa smp dalam melakukan operasi aljabar dan menguraikan bentuk aljabar ke dalam faktor. EKUIVALEN - Pendidikan Matematika, 13(2), 136-139.

Sutirman , M. P. (2013). Media \& Model-model Pembelajaran Inovatif. Yogyakarta: Graha Ilmu.

TheAsianparent Indonesia. (2014). survey tentang smartphone dan gadget yang mengejutkan. https://id.theasianparent.com/hasil-survey-smartphone-yangmengejutkan

Wardani, A, A. (2019). Pengembangan Media Quiet Book Untuk Meningkatkan Hasil Belajar Materi Ekosistem Kelas V SDN 2 Wrinnginanom Kecamatan Weinginanom Kabupaten Gresik. Jurnal Penelitian Pendidikan Guru Sekolah Dasar, 7(1), 2478-2491.

Wicaksono, D. P., Kusmayadi, T. A., \& Usodo, B. (2014). Pengembangan Perangkat Pembelajaran Matematika Berbahasa Inggris Berdasarkan Teori Kecerdasan Majemuk (Multiple Intelligences) Pada Materi Balok Dan Kubus Untuk Kelas VIII SMP. Jurnal Pembelajaran Matematika, 2(5), 534-549. 